\title{
Reproductive biology of the tub gurnard Trigla lucerna (linnaeus, 1758), in the Libyan eastern coast of Mediterranean Sea.
}

\author{
Ashraf I. Ahamed \\ Marine Science Department, Faculty of Science, Suez Canal University, Ismailia - \\ Egypt \\ E-mail: ashrafibrahim2002@yahoo.com
}

\section{ABSTRACT}

The reproductive biology of Trigla lucerna, (family: Triglidae) inhabiting Libyan eastern coast was studied during the period from January to December 2007. There were monthly variation in sex ratio, and a tendency for more females (731 fish, $52.2 \%$ ) than males (669 fish, $47.8 \%$ ) for the collected population. Overall sex ratio was 1: 1.09 for males to females. The male of Trigla lucerna attained its first maturity at the total length of $13.9 \mathrm{~cm}$, while the first sexual maturity of female was attained at $15.3 \mathrm{~cm}$. The gonado-somatic indices of males were lower than that of females. Males and females have a definite breeding season which extends from January till March. An increase in oocyte diameter was evident in November (with an average of $225 \mu$ ) and this increase continued in the following months till March, with an average value of $498 \mu$. The absolute fecunncldity ranged from 678 to 10047 eggs for fish length ranging from 13.5 to $22.6 \mathrm{~cm}$. Also, the fecundity increased from 755 to 10055 eggs with the increase of weight from 16.7 to $108.2 \mathrm{~g}$.

Key Words: Triglidae, Trigla lucerna, reproductive biology, Mediterranean Sea, Libyan eastern coast.

\section{INTRODUCTION}

Family Trigilidae includes bottom fish dwelers occurring over sand, muddysand or gravel at depth from 56 to $200 \mathrm{~m}$, but it is more common between 50 and100m (Richards and Saksena,1990). Trigla lucerna, called the tub gurnard, is the largest of the European gurnards, reaching a maximum length of $75 \mathrm{~cm}$, although most individuals are between 50-60 cm (Bauchot, 1987). Like all gurnards, it has a large head covered by protective bony plates, and the lower three rays of the pectoral fin are separated and fleshy (Muus and Nielsen, 1999). The tub gurnard is usually found on mud or sandy seabeds from 2-20m deep (Frimodt, 1995). Trigla lucerna is now recorded in IUCN Red list (IUCN, 2010). It is very common in the Mediterranean Sea and the Sea of Marmara, and in the eastern Atlantic from the British Isles to the coast of Senegal. It mainly feeds on small fish like sand eels, small flatfish, gobies, dragonets and also crabs and shrimbs (Moreira et al., 1992). This species is spawn in Eastern Atlantic from December till July (Richards, 1968) and caught with bottom trawls but also with long lines and band lines (Lewis and Yerger, 1976).

Few studies have been published on the biology of Triglid fishes especially in the Mediterranean Sea. Awad (1972) studied a comparative biological aspect on certain species of family Triglidae in the Mediterranean Sea off Alexandria. El-Mor (2002) studied some morphological characters of juveniles Trigla lucerna in Port Said Coast on the Egyptian Mediterranean Sea. Mytilineou et al. (2005) studied some ecological aspects on Trigla lucerna in Eastern Ionian Sea, but this is the first study 
so far on the reproductive biology of Trigla lucerna (family Triglidae) in the Libyan eastern coast.

\section{MATERIAL AND METHODS}

Monthly samples of Trigla lucerna were collected during the period from January to December 2007 by trawler net from Benghazi fishing areas and collected from the fishing harbor $\left(32^{\circ} 36^{\prime} \mathrm{N}\right.$ and $\left.20^{\circ} 03^{\prime} \mathrm{E}\right)$ on the Mediterranean Sea (Fig. 1).

A total of 1400 specimens of Trigla lucerna were used for studying the reproductive biology of the fish. Each fish was wet weighed in grams and its total length was measured in $\mathrm{cm}$, then it was dissected to determine sex then the gonads were removed and wet weighed to the nearest $\mathrm{mg}$. State of maturity for each individual fish was distinguished into four stages: virgin/resting, developing, active and post spawning (Buxton, 1989).

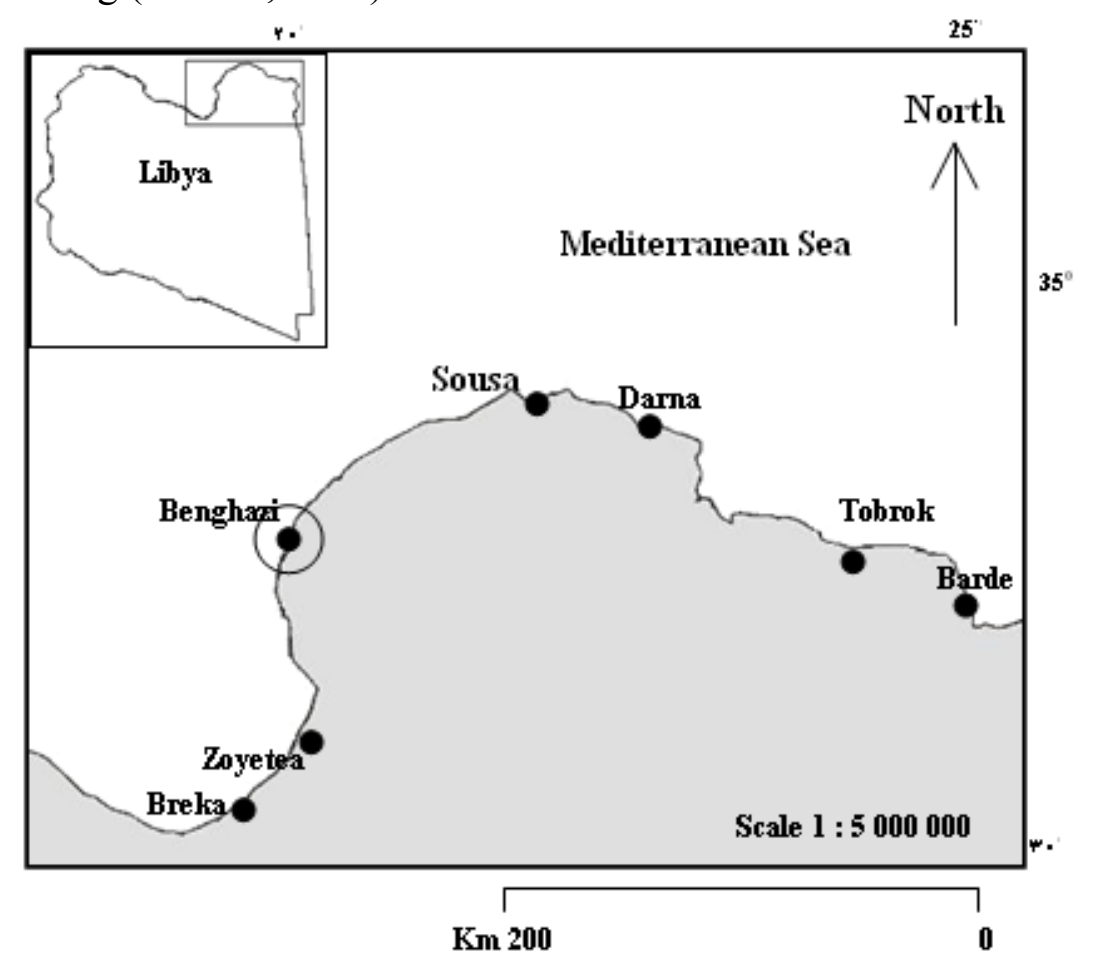

Fig. 1: Benghazi fishing harbor, on the Mediterranean Sea, Libya

The monthly Gonado-somatic index (G.S.I.) was calculated according to the following formula:

G.S.I. = wet weight of gonad (g) / wet weight of fish (g) X 100

Such indices were expressed as the monthly averages and plotted against months.

Oocyte diameters were measured to the nearest $0.01 \mathrm{~mm}$ by using an eyepiece micrometer. Oocytes were separated from the ovarian tissue and put in saline solution $(0.9 \% \mathrm{NaCl})$ for 24 hours, then they were measured under the microscope at $40 \mathrm{X}$, then 20 oocytes were taken randomly and their diameters were measured. The average oocyte diameters for mature specimens were calculated.

Fecundity was estimated by counting all ripe eggs found in the female ovary just prior to spawning season. Fish ovary was put in small divided Petri-dish; ova were separated from the ovarian tissue with the aid of a dissecting needle, and all ripe ova were counted under a binocular microscope. Fish length and total weight were 
recorded separately for each individual fish and plotted graphically against fecundity. The relationships between these variables and fecundity were estimated according the following formula:

$\log F=a \pm b \log x \quad$ (Bagenal, 1978)

Where $\mathrm{F}=$ absolute fecundity;

$\mathrm{X}=$ independent variables;

$\mathrm{a}=$ constant;

$\mathrm{b}=$ an exponent.

\section{RESULTS}

\section{Sex ratio}

Generally, there is a tendency for more females (731 fish, 52.2\%) than males (669 fish, 47.8\%) for the collected population. Overall sex ratio was 1: 1.09 for males to females (Table 1). The sex ratio was not constant throughout different months. The numbers of females exceeded males in all months except in the period from April till August.

Table 1: Monthly variations in sex ratio of Trigla lucerna from Benghazi coast.

\begin{tabular}{|c|c|c|c|c|c|c|}
\cline { 3 - 6 } \multicolumn{2}{c|}{} & \multicolumn{2}{c|}{ Males } & \multicolumn{2}{c|}{ females } & \multicolumn{1}{c}{} \\
\hline Months & No. of fish & No. & $\%$ & No. & $\%$ & Sex ratio \\
\hline Jan. & 121 & 48 & 39.7 & 73 & 60.3 & $1: 1.52$ \\
\hline Feb. & 82 & 32 & 39.0 & 50 & 61.0 & $1: 1.56$ \\
\hline Mar. & 57 & 22 & 38.6 & 35 & 61.4 & $1: 1.59$ \\
\hline Apr. & 82 & 49 & 59.8 & 33 & 40.2 & $1: 0.67$ \\
\hline May & 140 & 78 & 55.7 & 62 & 44.3 & $1: 0.80$ \\
\hline Jun. & 198 & 109 & 55.1 & 89 & 44.9 & $1: 0.81$ \\
\hline Jul. & 180 & 93 & 51.7 & 87 & 48.3 & $1: 0.93$ \\
\hline Aug. & 173 & 88 & 50.9 & 85 & 49.1 & $1: 0.96$ \\
\hline Sep. & 81 & 40 & 49.4 & 41 & 50.6 & $1: 1.02$ \\
\hline Oct. & 80 & 40 & 50.0 & 40 & 50.0 & $1: 1.00$ \\
\hline Nov. & 105 & 39 & 37.1 & 66 & 62.9 & $1: 1.70$ \\
\hline Dec. & 101 & 31 & 30.7 & 70 & 69.3 & $1: 2.26$ \\
\hline Total & 1400 & 669 & 47.8 & 731 & 52.2 & $1: 1.09$ \\
\hline
\end{tabular}

\section{Size at first sexual maturity}

The first appearance of mature males was recorded at a length group of (12$12.9 \mathrm{~cm}$ ) by $24.5 \%$ and the smallest male of Trigla lucerna attained its first maturity (50\% of males) at $13.9 \mathrm{~cm}$. length (Fig. 2). On the other hand, the sign of mature females was recorded at a length group of $(13-13.9 \mathrm{~cm})$ representing $12.5 \%$ of females examined. The size at which $50 \%$ of females were mature could be taken as $15.3 \mathrm{~cm}$.

\section{Maturity stages}

Data of monthly changes of sexual maturity are represented in Figure (3). Males had virgin / resting testes (stage I) in August (100\%). During the following two months (September and October) virgin / resting testes dominated the population, being $81.9 .3 \%$ and $64.5 \%$ respectively. The first sign of developing stage appeared during the period from September (18.1\%) till March (2.3\%). An active testes appeared in January by $52.2 \%$ of the population increased during February $(82.5 \%)$ and December (91.9\%). Post spawning (stage IV) testes amounted to $2.3 \%$ in February and $5.8 \%$ in March of the examined specimens. 

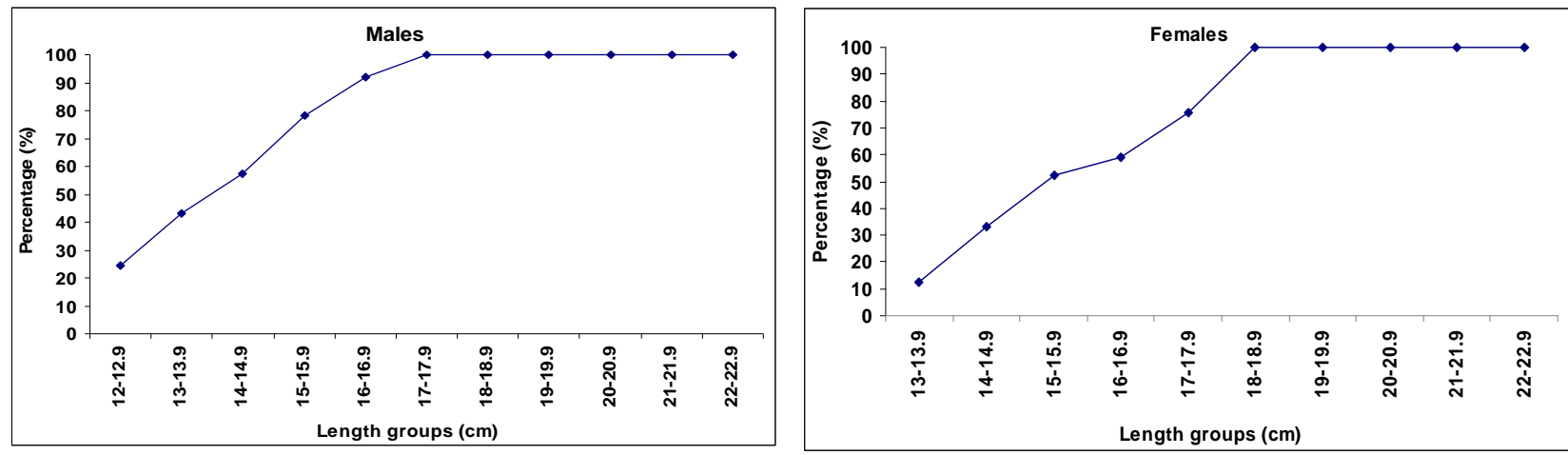

Fig. 2: Length at first maturity of Trigla lucerna from Benghazi coast
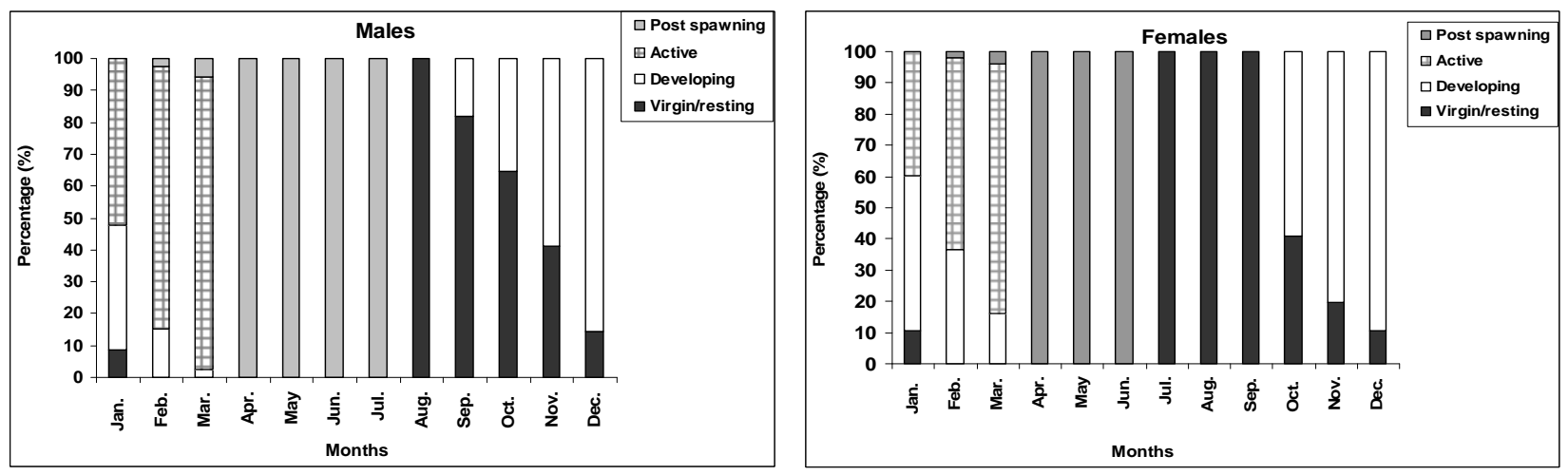

Fig. 3: Monthly changes in the stages of sexual maturity in Trigla lucerna from Benghazi coast.

Females with a virgin / resting (stage I) were dominant during July, August and September (100\%). The first appearance of developing ovaries was present in October (58.8\%), November (80.4\%), December (89.5\%), January (49.5\%), February (36.5\%) and March (16.1\%). The first sign of active ovaries (stage III) appeared in January by $39.9 \%$ and continued in February by $61.6 \%$, reaching the maximum value in March by $79.8 \%$. During February and March, females were post spawning (stage IV) with a ratio between $1.9 \%$ and $4.1 \%$ respectively. The stage (IV) of post spawning was represented by $100 \%$ for males and females in the study area during April and June.

\section{Gonado-somatic indces (G.S.I.)}

The monthly changes in G.S.I. are represented in Fig. (4). Trigla lucerna showed a definite breeding season, which extends from January till March in the Libyan eastern coast.

The male G.S.I. attained lower values than those of females. The average male G.S.I. increased from November (1.78) till December (2.23), then increased sharply from January (3.79) till February (3.91). The highest value of males G.S.I. was recorded in March (4.12).

In females, the values of G.S.I. was recorded in September, October, November and December, being 2.26, 2.47, 2.58 and 2.72 respectively, then increased sharply from January (4.45) till February (4.91). The highest value of females G.S.I. (5.25) was recorded in March.

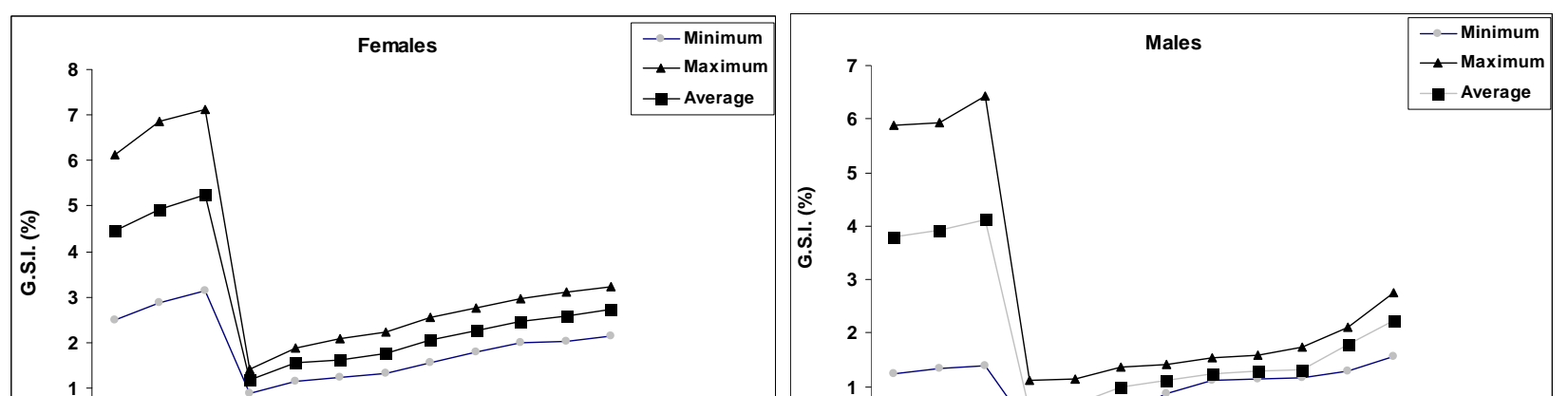


Fig. 4: Monthly variations in the average gonado-somatic indices of Trigla lucerma ferom Benghazi coast.

\section{Oocyte diameter}

The recorded average oocyte diameters of Trigla lucerna, during the whole period of the study are represented in Table (2). The smallest average oocyte diameter was recorded in August $(139 \mu)$, then gradually increased in November $(225 \mu)$ and December $(270 \mu)$, and this increase continued in the following months, reaching $(465 \mu)$ in January then $(480 \mu)$ in February and reched the maximum value in March, with an average of $(498 \mu)$. The egg diameter in fish samples was very minute and difficult to measure in April, May, June and July.

Table 2: Monthly variations of oocyte diameters of Trigla lucerna from Benghazi coast.

\begin{tabular}{|c|c|c|c|c|}
\hline \multirow{2}{*}{ Months } & \multirow{2}{*}{ Number of fish } & \multicolumn{3}{|c|}{ Egg-Diameters $(\mu)$} \\
\cline { 3 - 5 } & & Minimum & Maximum & Average \\
\hline Jan. & 58 & 411 & 522 & 465 \\
\hline Feb. & 43 & 426 & 536 & 480 \\
\hline Mar. & 32 & 439 & 545 & 498 \\
\hline Apr. & 33 & $\mathrm{~A}$ & $\mathrm{~A}$ & $\mathrm{~A}$ \\
\hline May & 62 & $\mathrm{~A}$ & $\mathrm{~A}$ & $\mathrm{~A}$ \\
\hline Jun. & 89 & $\mathrm{~A}$ & $\mathrm{~A}$ & $\mathrm{~A}$ \\
\hline Jul. & 87 & $\mathrm{~A}$ & $\mathrm{~A}$ & $\mathrm{~A}$ \\
\hline Aug. & 85 & 89 & 187 & 139 \\
\hline Sep. & 41 & 103 & 206 & 155 \\
\hline Oct. & 40 & 112 & 277 & 198 \\
\hline Nov. & 66 & 145 & 305 & 225 \\
\hline Dec. & 70 & 196 & 345 & 270 \\
\hline
\end{tabular}

$\mathrm{A}=$ The egg diameters were very minute and difficult to measure

\section{Fecundity}

Two terms are applied in fish fecundity studies; the absolute fecundity which is the total number of mature eggs in the ovary and the relative fecundity which is the number of eggs per unit length or weight of the fish (Nikolsky, 1963). Ovaries of 133 Trigla lucerna were examined. The smallest mature female had a total body length of $12.9 \mathrm{~cm}$ and body weight of $21.9 \mathrm{~g}$. Its ovary weight was $0.34 \mathrm{~g}$. $(2.1 \%$ of the body weight), with absolute fecundity of 133 ripe eggs. The largest female had a total body length of $23.2 \mathrm{~cm}$ and body weight of $116.9 \mathrm{gm}$, whereas its ovary weight was $8.33 \mathrm{~g}$ and its absolute fecundity was 10047 ripe eggs.

The relationship between the body length and absolute fecundity of Trigla lucerna is given in Table (3) and Fig. (5). The absolute fecundity of 133 ripe females ranged from 678 to 10047 with an average of 5010 ripe eggs/fish and with an average 
relative fecundity of 254 ripe eggs/ $\mathrm{cm}$. It is clear that both the absolute and relative fecundity increased with the increase of total length. Data of absolute fecundity with total length are represented by the following equation: $\mathrm{F}=0.0005 \mathrm{~L}{ }^{5.4891}$ Where, $\mathrm{F}$ is absolute fecundity and $\mathrm{L}$ is the total body length. The relation is highly significant and a correlation coefficient 0.965 was calculated.

Table 3: Relation betweeen fecundity and total length $(\mathrm{cm})$ of Trigla lucerna from Benghazi coast.

\begin{tabular}{|c|c|c|c|c|c|c|c|}
\hline & & & \multicolumn{4}{|c|}{ Absolute Fecundity } & Relative \\
\hline \multicolumn{2}{|c|}{ Total length $(\mathrm{cm})$} & & & & & & Fecundity \\
\hline Range & Mid length & No. & Minimum & Maximum & Average & Calculated & F/T.L. $(\mathrm{cm})$ \\
\hline $12.9-14.1$ & 13.5 & 35 & 542 & 714 & 678 & 801 & 50 \\
\hline $14.2-15.4$ & 14.8 & 26 & 817 & 1243 & 1036 & 1326 & 70 \\
\hline $15.5-16.7$ & 16.1 & 15 & 1989 & 3429 & 2557 & 2106 & 159 \\
\hline $16.8-18.0$ & 17.4 & 12 & 2453 & 4521 & 3742 & 3225 & 215 \\
\hline $18.1-19.3$ & 18.7 & 10 & 4238 & 6235 & 5124 & 4789 & 274 \\
\hline 19.4-20.6 & 20.0 & 10 & 5888 & 8429 & 7147 & 6926 & 357 \\
\hline $20.7-21.9$ & 21.3 & 12 & 9754 & 9754 & 9754 & 9785 & 458 \\
\hline $22.0-23.2$ & 22.6 & 13 & 9858 & 10236 & 10047 & 13546 & 445 \\
\hline
\end{tabular}

No. $=$ number of specimens

T.L. $=$ total length

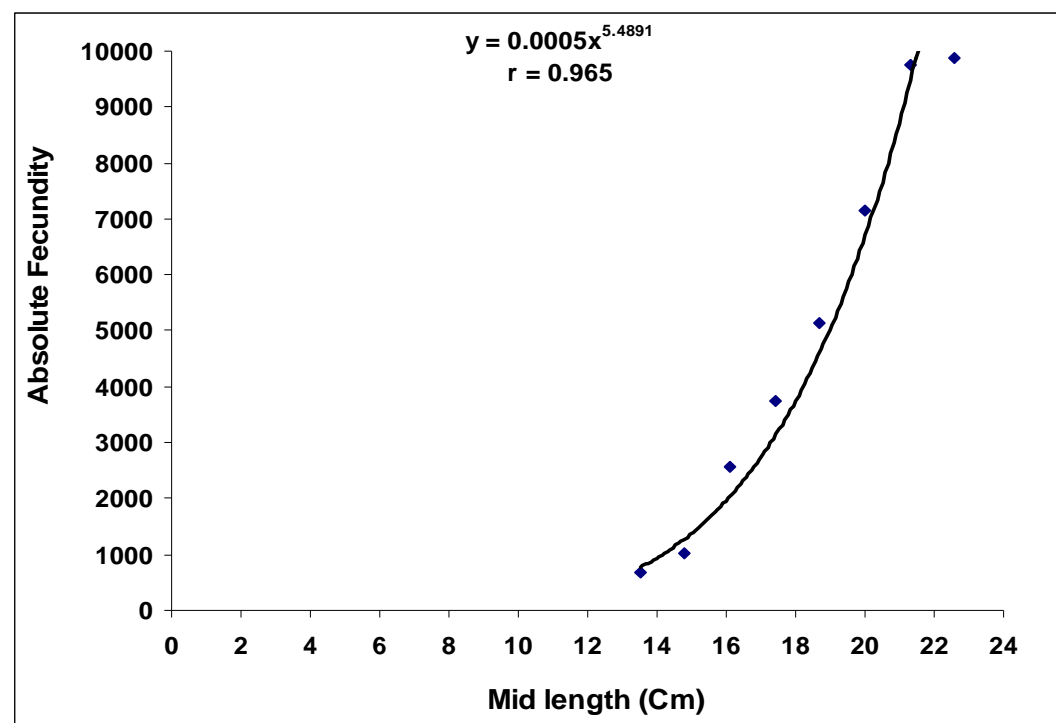

Fig. 5: Relation between mid length and absolute fecundity of Trigla lucerna from Benghazi coast.

Results of the relationship between the absolute fecundity and body weight of T. lucerna are given in Table (4) and Figure (6). Absolute fecundity ranged from 755 to 10055 , with an average of 5018 ripe eggs / fish and with an average relative fecundity weight of 72 ripe eggs / g, so the fecundity increased with increasing body weight. The regression relationship was represented by the following equation:

$$
\mathrm{F}=11.618 \mathrm{~W}^{1.4538}
$$

Where, $\mathrm{F}$ is the absolute fecundity and $\mathrm{W}$ is the total body weight. The relationship is highly significant with correlation coefficient of 0.9941 . 


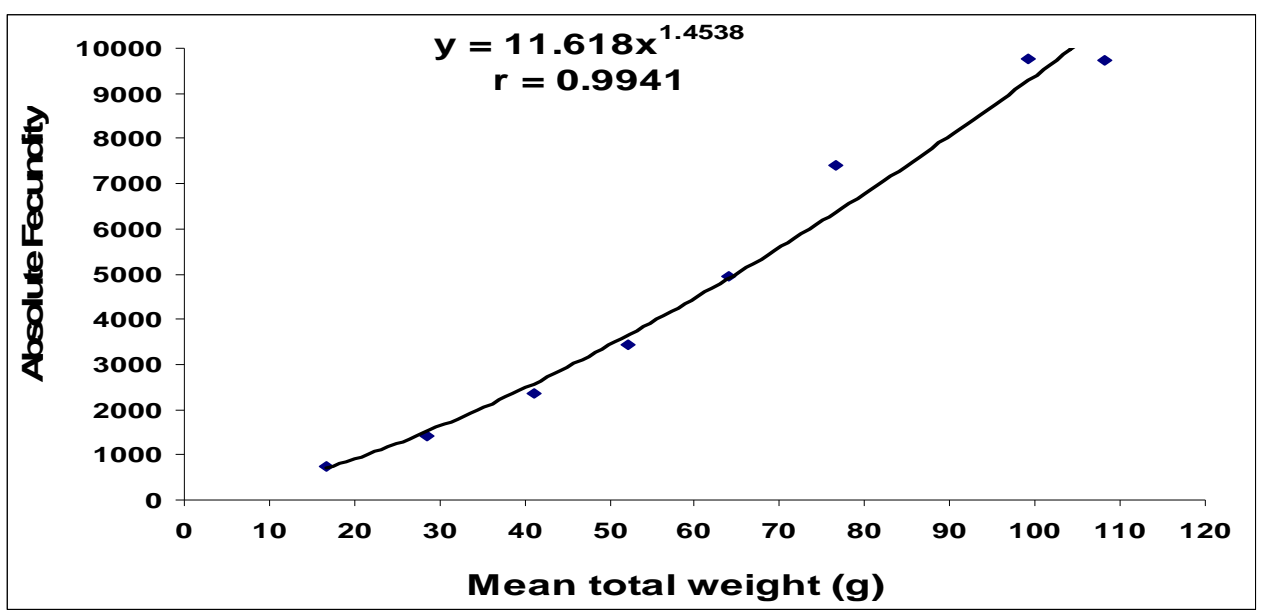

Fig. 6: Relation between mean total weight and absolute fecundity of Trigla lucerna from Benghazi coast.

\section{DISCUSSION}

Triglid fishes inhabit tropical and temperate coastal water. They are found near the shore in shallow inlets and bays less often at moderate depths (Frimodth, 1995). Trigla lucerna is the largest and oldest of the Eutopean gurnards, reaching a maximum length of $75 \mathrm{~cm}$ and 15 years (Baron, 1985). It is usually found on mud or sand seabeds from 2-20m depth (Frimodth, 1995).

In the current study, the overall sex ratio was 1: 1.09 for males and females of Trigla lucerna and these results are in full agreement with sex ratio of other species of family Triglidae in the Mediterranean Sea (Mytilineou et al., 2005). In the persent work, the sex ratio was not constant throughout different months, particularly during the breeding season of each species (Oren, 1975). In the period from April till August (after the spawning season), the males of Trigla lucerna were dominant over the females in agreement with Baron, (1985) who studied sex ratio of Trigla lucerna in the French Mediterranean Sea. Also these phenomena were shown by other fish species such as mullet species (Mohammad, 1982 and El-Mor, 1993). In addition, Wijeyaratne and Costa (1986) concluded that it is possible that males of grey mullets are more active before spawning season and get caught in the gear in large numbers, resulting in an unbalanced sex ratio.

In the period from September till March, the numbers of females exceeded males since the males might migrate for spawning elsewhere before females as recorded by Awad (1972) that such phenomena of sex ratio for Trigla lucerna in the Mediterranea Sea off Alexandria.

Generally, in the natural fish community males mature first before females, and become ready to participate in spawning activity (Mohammad, 1982 and El-Mor, 1993). In the present study, the first appearance of mature males was recorded at length group $(12-12.9 \mathrm{~cm})$ by $24.5 \%$ and the smallest male of $T$. lucerna attained its first maturity at the total body length of $13.9 \mathrm{~cm}$. On the other hand, the first sign of mature females was recorded at length group of $13-13.9 \mathrm{~cm}$, representing $12.5 \%$ of the examined females, while the first sexual maturity of the female was attained at size at which $50 \%$ of females were mature could be taken as $15.3 \mathrm{~cm}$. This nearly agrees with what had been recorded by Baron (1985) who stated the smallest male of Trigla 
lucerna inhabiting the French Mediterranean Sea attained its first maturity at the total body length of $14.1 \mathrm{~cm}$ and $15.5 \mathrm{~cm}$ for females.

In the present study, the average gonado somatic indices (G.S.I.) of males were lower than those of females. The males and females of T. lucerna showed a definite breeding season, which extends from January till March, with maximal G.S.I. of 4.12 and 5.25 in March for males and females respectively. The increase of G.S.I. during the breeding season is mainly due to the deposition of large amounts of proteins and lipids in the developing eggs and spermatozoa. A part of these materials comes directly from ingested food but a major proportion comes from the reserve of food deposits, during the active season, in organs such as liver, muscles and fat bodies (Larson, 1974). The spawning season of the target species agrees with that, in other sites on the Mediterranean Sea as reported by Baron (1985) that it extends from January till April, and then from December till March in the Eastern Ionian Sea (Mytilineou,et al., 2005). The time of spawning season in the present study coincided with the appearance of the juveniles and fry of the fish in the Mediterranean Sea. ElMor (2002) recorded juveniles of Trigla lucerna in Port Said coast on the Egyptian Mediterranean Sea in the period from April till July while the eggs and fry of the same fish were detected in British water by Russel (1976).

In the current work, the increase in the oocyte diameters of T. Lucerna was evident in October with an average of $277 \mu$ and this increase continued in the following months till March, with a maximal average value of $545 \mu$. In April till July, all fish samples were immature and the egg diameters were very minute and difficult to measure. These results coincide with those recorded by Mytilineou et al. (2005) and Baron (1985) who stated that the egg diameters reached $512 \mu$ and $550 \mu$ in February and March respectively.

The number of eggs produced by females varies greatly according to species , size, age, region, period and techniques used, thus a considerable variability has been shown in different populations (Oren, 1975).

Baron (1985) found that the absolute fecundity ranged from 606 to 9004 for females ranging from 13.9 to $24.8 \mathrm{~cm}$ in total length. In the present study, the absolute fecundity of 133 ripe females ranged from 678 to 10047 with the growth in length from 13.5 to $22.6 \mathrm{~cm}$. Also, the fecundity increased from 755 to 10055 with the increase in weight from 16.7 to $108.2 \mathrm{~g}$.

\section{REFERENCES}

Awad, H. E. (1972). A comparative study on certain species of family Triglidae in the Mediterranean Sea off Alexandria. M.Sc. Thesis, Faculty of Science. Alexandria University.

Bagenal, T. B. (1978). Fish fecundity and its relations with stock and recruitment.Rapp. P-V. Reum. Cons perm. Int. Explor. Mer., 164:186-198.

Buxton, C, D. (1989). Protogynous hermaphroditism in Chrisoblephus laticeps (Cuvier) and C. cristiceps (Cuvier) (Teleosti: Sparidae) S. Afr. J. Zool., 24:212-216.

Bauchot, M. L. (1987). Poissons osseux. P. 891-1421. In Fischer, W.; Bauchout, M. L. $\quad$ and Schneider, M. (eds.) Fishges FAO d' identification pour les besoins de la peche. (Rex.1). Mediterranee et mer Noire. Zone de Peche 37. Vol. II. Commission des Communautes Europeennes and FAO. Rome. 
Baron, J. (1985). Les Triglides (Teleosteens, Scorpaeniformes) de la baie de douarnenez. II. La reproduction de. Eutrigla gurnardus, Rrigla lucerna, Trigloparus lastoviza et Aspitrigla cuculus. Cybium 9: 255-261.

Broadhead, G. C. (1953). Investigations of the black mullet (Mugil cephalus L.) in northwest Florida. Fla. State Bd conserve., 7:1-33.

Costa, M. J. (1988). Ecologie alimentaire des poisons de 1 'estuarie du tage. Cybium. 12 (4). 301-320.

El-Mor, M. (1993). Fisheries and biological studies on some species of family Mugilidae inhabiting the Suez Canal. M.Sc. Thesis, Faculty of Sci., Suez Canal Univ., ARE, pp.100.

El-Mor, M. (2002). Ecological and biological studies on commercial juvenile fishes from Port Said coast. Ph.D. Thesis, Faculty of Sci., Suez Canal Univ., ARE, $215 \mathrm{pp}$.

Frimodth, C. (1995). Multlingual illustrated guide to the world's commercial cold water fish. Fishing news books, Osney Mead, Oxford, England. 215pp.

IUCN (2010). 2010 IUCN Red list of threatened species. Version 2010.2.

Lewis, T. C. and Yerger, R. W. (1976). The biology of five species of sea robins (Pisces, Triglidae) from the Northeastern Gulf of Mexico. Fishery Bulletion 74(1): 93-103.

Larson, G. L. (1974). Liver weight of brook trout in a high mountain lake in Washington State. Prog. Fish. Cult., 35:234-236.

Mohammad, S. Z. (1982). Biological studies on fishes of Lake Timsah. M. Sc. Thesis, Faculty of Sci., Suez Canal Univ., ARE, 100 pp.

Muus, B. J. and Nielsen, J. G. (1999). Sea fiush. Scandinavian Fishing Year Book, Hedehusene, Demark, 340pp.

Mytilineou, C.; Politou, C. Y.; Papaconstantinou, C.; Kavadas, S. D onhia, G. and Sion, L. (2005). Deep-water fish fauna in the Eastern Ionian Sea. Belg. J. Zool., 135 (2): 229-233.

Oren, O. H. (1975). Opening address IBP/PM international symposium on the grey mullet and their culture. Aqua., 5:3-8.

Peterson, G. L. and Shehadeh, Z. H. (1971). Subpopulations of the Hawaiian grey mullet Mugil cephalus: Analysis of variation of nuclear eye lens protein electrophoregrams nuclear eye-Lens weights. Mar. Biol., 11(1): 52-60.

Richards, W. J. and Saksena, V. P. (1990). Triglida. P. 680-684. In Quero, J. C.; Hureau, J. C.; Karrer, C.; Post, A. and Saldanha, L. (eds.). Check list of the fishes of the eastern tropical Atlantic (CLOFETA). JNICT, Lisbon; SEI, Paris; and UNESCO, Paris. Vol.2.

Richards, W. J. (1968). Eastern Atlantic Triglidae (Pisces, Scorpaeniformes). Contributions from the biological laboratory of Science of China. (Zoological Series. No. 10:77-114.

Russel, F. S. (1976). The eggs and planktonic stages of British marine fishes. Academic Press, London, Uk. 524pp.

Wijeyaratne, M. S. and Costa, H.H. (1986). Fishery seasonal abundance and maturity of grey mullets (Pisces: Mugilidae) in Negombo Lagoon, Srilanka. J. Appl. Chthyol., 3:115-118. 


\section{(LINNAEUS, 1758), بيولوجية التكاثر لسمكة الفرخة (تريجلا لوسرينا) (لشاطئ الشرقى الليبى للبحر المتوسط (175

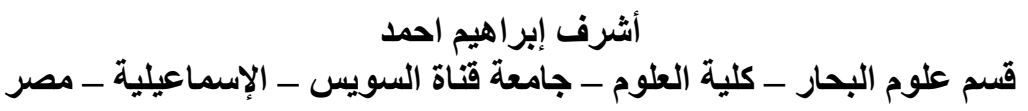

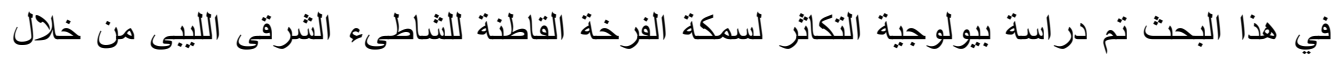

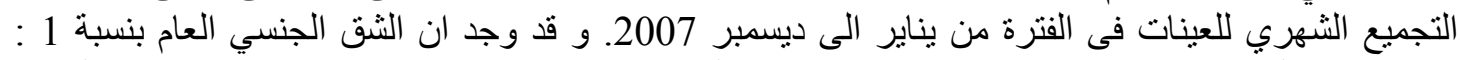

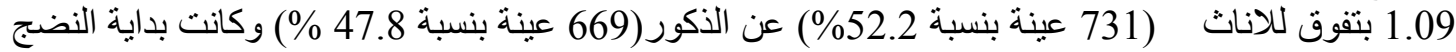

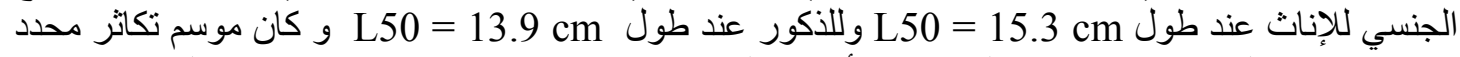
يمتد من يناير إلى مارس وتحدث الزيادة فى أحجام البويضات في نوفمبر (225ر) ثم تستمر الزيادة وصولات لشهر مارس (4984).

و كانت الخصوبة المطلقة للسمكة تتراوح بين 678 إلى 155 الى 10047بويضة للأطو ال من 13.5 إلى 22.6

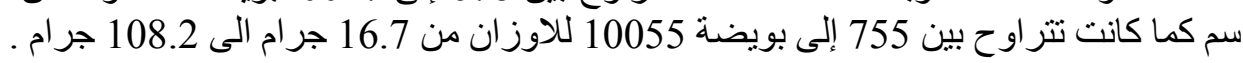

